\title{
CORRESPONDENCE
}

\section{More Information about Postbaccalaureate PharmD Training}

We read with interest Amy Smith's correspondence ${ }^{1}$ in a recent issue of the CJHP. While we were pleased to see this description of Canadian postbaccalaureate PharmD programs, we were disappointed that the author did not present all options for such training that are currently available in Canada. Here, we would like to highlight another program that is available to Canadian pharmacists.

The Faculty of Pharmacy and Pharmaceutical Sciences at the University of Alberta launched Canada's first nontraditional postprofessional PharmD program in September 2013. This 13-month, full-time program includes 36 weeks of experiential training along with 13 weeks of didactic education. The didactic portion of the program emphasizes patient care processes and critical thinking skills through problem-based and active learning methodologies. The program currently admits newly graduated and experienced pharmacist practitioners from across Canada who are eligible to be licensed in Alberta and who are authorized to administer injections (these requirements may be fulfilled after admission to the program). The class size was initially 10 students, increased to 16 students in fall 2014, and is expected to grow further over the coming years. In addition, within the next 1 or 2 years, the Faculty is planning to introduce a flexible distance PharmD program, as well as a bridging program (Table 1).

\section{Reference}

1. Smart A. Postbaccalaureate PharmD programs for Canadian pharmacists: options and considerations [letter]. Can J Hosp Pharm. 2014;67(4):313-4.

Rene Breault, BScPharm, PharmD

Director, Post-Professional PharmD Program

Jill Hall, BScPharm, PharmD, ACPR

Clinical Assistant Professor

James $\mathbf{P}$ Kehrer, PhD

Professor and Dean

Faculty of Pharmacy and Pharmaceutical Sciences

University of Alberta

Edmonton, Alberta

Competing interests: None declared.

\section{Table 1. Postbaccalaureate PharmD Programs in the Faculty of Pharmacy and Pharmaceutical Sciences, University of Alberta}

\begin{tabular}{llll} 
Type of Program & \multicolumn{1}{c}{ Duration } & \multicolumn{1}{c}{ Cost } & \multicolumn{1}{c}{ Class Size } \\
\hline Full-time & $\begin{array}{l}\text { Total 13 months } \\
\text { (including 9 months } \\
\text { experiential) }\end{array}$ & About Can $\$ 23000$ & $\begin{array}{l}\text { Variable (up to } \\
30 \text { students) }\end{array}$ \\
\hline $\begin{array}{l}\text { Flexible distance } \\
\text { program* }\end{array}$ & $\begin{array}{l}\text { Variable } \\
\text { (up to 5 years) }\end{array}$ & $\begin{array}{l}\text { Details not yet } \\
\text { available }\end{array}$ & Variable \\
\hline
\end{tabular}

*Anticipated for 2016.

\begin{tabular}{lcc}
\multicolumn{2}{c}{ Advertisers } & \\
\hline & Ad Page & Prescribing Information \\
\hline Baxter / Corporate & 407 & - \\
\hline Pfizer / Injectables & 402 & - \\
\hline Pfizer / Injectables & 404 & - \\
\hline Pharmaceutical Partners of Canada / Heparin & IFC & - \\
\hline Pharmaceutical Partners of Canada / Corporate & OBC
\end{tabular}

